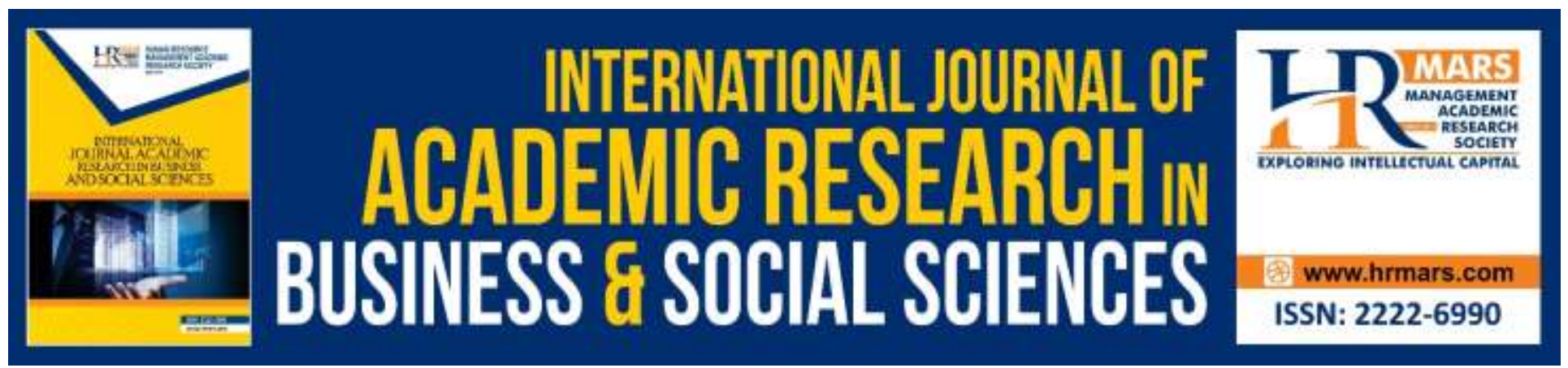

\title{
Integrative and Instrumental Motivation among the Chinese Language Pre-service Teachers
}

Tan Chor Ter, Chew Fong Peng, Fonny Hutagalung, Zanariah Hamid

To Link this Article: http://dx.doi.org/10.6007/IJARBSS/v9-i6/6083 DOI: 10.6007/IJARBSS/v9-i6/6083

Received: 07 April 2019, Revised: 12 May 2019, Accepted: 02 June 2019

Published Online: 24 June 2019

In-Text Citation: (Ter, Peng, Hutagalung, \& Hamid, 2019)

To Cite this Article: Ter, T. C., Peng, C. F., Hutagalung, F., \& Hamid, Z. (2019). Integrative and Instrumental Motivation among the Chinese Language Preservice Teachers. International Journal of Academic Research in Business and Social Sciences, 9(6), 1216-1227.

Copyright: (C) 2019 The Author(s)

Published by Human Resource Management Academic Research Society (www.hrmars.com)

This article is published under the Creative Commons Attribution (CC BY 4.0) license. Anyone may reproduce, distribute, translate and create derivative works of this article (for both commercial and non-commercial purposes), subject to full attribution to the original publication and authors. The full terms of this license may be seen

at: http://creativecommons.org/licences/by/4.0/legalcode

Vol. 9, No. 6, 2019, Pg. 1216 - 1227

http://hrmars.com/index.php/pages/detail/IJARBSS

JOURNAL HOMEPAGE

Full Terms \& Conditions of access and use can be found at http://hrmars.com/index.php/pages/detail/publication-ethics 


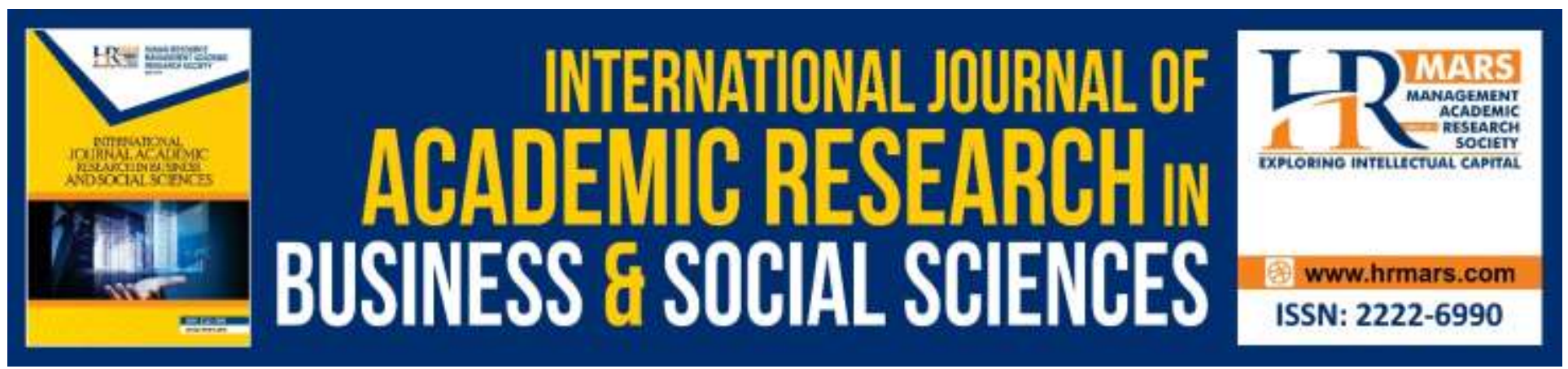

\section{Integrative and Instrumental Motivation among the Chinese Language Preservice Teachers}

\section{Tan Chor Ter, Chew Fong Peng, Fonny Hutagalung, Zanariah Hamid}

Department of Language and Literacy Education Faculty of Education, University of Malaya, Malaysia.

\section{Abstract}

The present study intended to investigate Chinese proficiency achievement, integrative and instrumental motivation among Malaysia Chinese Language pre-service teachers. Integrative and instrumental motivation are two psychology factors that directly influence Chinese proficiency. The samples consisted of pre-service Chinese teachers attending undergraduate and postgraduate diploma teacher education programs. 407 samples from five Malaysian Teacher Training Institutes participated in this study. The analysis revealed three importance findings. First, the undergraduate pre-service teachers' Chinese proficiency test results were better than the postgraduate diploma preservice teachers. Secondly, the mean of integrative and instrumental motivation of undergraduate pre-service teachers was higher than postgraduate diploma pre-service teachers. Thirdly, the $t$ test showed that the mean of integrative and instrumental motivation significantly differed between undergraduate with postgraduate diploma teacher education programs.

Keywords: Integrative, Instrumental, Motivation, Teacher Education, Chinese Proficiency.

\section{Introduction}

Malaysia's Education Blueprint (MOE, 2013) emphasis that high-quality teachers can produce good education for every student to improve the national education's quality. Therefore, teacher education is the first step in cultivating teachers' professional knowledge and attitude. According to Foo (2005), every school needs qualified teachers who teach according to their major subject.

Since July 13, 2005, the Malaysian Education Department has approved all teacher education college be upgraded to Malaysian Teachers Training Institute to produce teachers with a bachelor's degree. At present, there are 27 teachers training institutes in Malaysia, 14 of which offer Chinese language teacher education (Ghazali \& Mahmud, 2008). The Chinese language teacher education program is divided into the undergraduate teacher education program and the diploma in education for postgraduate teacher education program. 
INTERNATIONAL JOURNAL OF ACADEMIC RESEARCH IN BUSINESS AND SOCIAL SCIENCES Vol. 9, No. 6, June, 2019, E-ISSN: 2222-6990 @ 2019 HRMARS

\section{Problems of Statement}

The Malaysia Chinese teacher education program is divided into the postgraduate diploma in education for postgraduate preservice teachers who hold a degree in teaching Chinese as a foreign language from a university in China. The undergraduate program for fresh high school students can be completed in five years. The postgraduate diploma in education program is for non-native speakers but the undergraduate program is for native speakers or Chinese language preservice teachers. Moreover, the pre-service Chinese language teachers come from different backgrounds, cultures and races.

Mastery in the Chinese language is a challenge for non-native Chinese language preservice teachers. Ng, Wong, Guek, Lim \& Tan (2017) stated that non-native speakers of the Chinese language are able to communicate in Chinese fluently with Chinese lecturers and native speakers. However, the study showed that preservice teachers who are non-native speakers of were poor in phonetics and lacked vocabulary. They repeated to make the same errors in reading teaching and could not avoid adding Malay vocabulary to explain the Chinese words when teaching. The Chinese words, which are in a logographic pattern, is a burden to non-native speakers as they must remember the meaning and sounds of all the different words' when reading. The problem of phonetics and intonations in Chinese language mastery level among preservice non-native speaking teachers leaves a negative impression on school children and disrupts communication and discussions between teachers and students (Mora \& Darcy, 2017).

In a similar vein, Lam, Yau, Yoe, Chew, Lee and Lee (2006) revealed that preservice native speaking teachers were also weak in mastering the Hanyu Pinyin (汉语拼音) phonetics. The preservice teachers cannot correctly demonstrate by reading aloud to students. Hence, they face difficulty in distinguishing different intonations and tunes in Hanyu Pinyin. The study clearly points out that Malaysian Chinese's education, culture and language has been localised. Although the Malaysian Chinese share the traditional culture and language (Mandarin) from mainland China, the geographical distance between Malaysia with China has made the difference, especially the change in living conditions and lifestyle, thus influencing language identity patterns and cultural choice of the local Chinese.

The Chinese language usage environment in Malaysia is influenced by Chinese dialects. According to Koh (2008), the Malaysian Chinese community still adheres to the ancestral family dialect. In Chinese families, parents are comfortable in communicating in their dialect language. Neo (2012) pointed out that Malaysian Chinese dialects can be divided into five categories, namely Min, Cantonese, Chaozhou, Hakka, and Hainan. Families in the Chinese community keep their own name found in the dialect language to preserve their identity and culture. Even though different dialect groups can read and understand Chinese characters in terms of different pronunciations, the vocabulary and sentence structure are sufficient to cause them to incorrectly pronounce Chinese words in Hanyu Pinyin. Therefore, multi dialect linguistics has influenced preservice native speaking teachers' phonetic mastery in Hanyu Pinyin.

According to Adler (2008), teachers face challenges such as stress and complex issues surrounding teacher education today. Hence, if teacher education aims to produce qualified teachers, the teacher education practice must raise its positive motivation level in language learning to master a high proficiency level in Chinese language. Chinese language teachers must prepare 
themselves to be able to teach the Chinese language in various environments. The same goes to nonnative Chinese language speaking teachers who face problems in mastering the Chinese culture and linguistics. Hence, differences in socio-cultural elements is an importance factor that affects the preservice teachers' language and culture knowledge (Cui, 2010). In addition, Chinese language teachers are expected to master language skills, such as listening, speaking, reading and writing language skills (Guo, 2012). Therefore, preservice teachers must be well-prepared to meet "real world" problems and technical skills in teaching Chinese language and culture.

Since Gardner and Lambert (1972) initiated orientation and attitude in the second language learning field, integrative and instrumental motivation has become an important focus for language learning researchers (Gardener, 1985; 2001; 2006; Gardner, Masgoret, Tennant \& Mihic, 2004; Tremblay \& Gardner, 1995). Previous studies had defined integrative motivation and instrumental motivation as variables that are highly associated with success and achievement. Gardner (1985, 2001) also stated that integrative motivation is positively related to language achievement, while instrumental motivation is negatively related to language achievement.

According to the education psychology model (Gardner, 1985; 2001), integrative and instrumental motivation influences the learning process. Integrative motivation refers to the learners' desire to learn a language in order to identify with the target community's culture, openness, and acculturation to the heritage culture. However, instrumental motivation refers to values of language proficiency, such as to obtain better career opportunities. Thus, different orientation motivations has led to different goals, wills and attitudes to achieve the learning outcome, although they are learning the same curriculum, using similar learning materials and situated in the same classroom.

Gardner (2006) stated that cultural and educational contexts on motivation affected the language learners' behaviour, persistent cultural contacts, and language retention. Integrative motivation is the central component of Gardner's social-education model. The integrative motivation emphasize that interact with different culture and psychologically accept the different culture be as part of life (Gardner, 2001). Furthermore, the differential individual personal background and individual history that could play a role to change individual motivation, belief, behavior to achieve learning goal and acquisition.

Lai $(2012,2011,2005)$ was the first researcher to study Hong Kong secondary school students regarding their integrative and instrumental orientation toward national language (Mandarin), foreign language (English) and their mother tongue (Cantonese dialect). Lai (2012, 2011, 2005) had clarified that China's modern culture, politic power, strength economic, lifestyle, business and social life had directly affected integrative and instrumental orientation towards learning Mandarin, English and Cantonese. The findings revealed that learners can have multiple or complex identities. The language learners correspond more to the language that plays the role of social change. This is because language learners are more aware of future needs and demands needed to enhance the social status and guarantee a successful future.

Previous studies had discussed integrative and instrumental motivation in a second language learning environment from school students and high school second language learners. However, studies in language learning in a multicultural or multilingual environment concerning Chinese language proficiency in Chinese preservice teachers are still lacking. Hence, this study aimed 
INTERNATIONAL JOURNAL OF ACADEMIC RESEARCH IN BUSINESS AND SOCIAL SCIENCES

Vol. 9, No. 6, June, 2019, E-ISSN: 2222-6990 (C) 2019 HRMARS

to reveal the different integrative and instrumental motivations that influence Chinese language proficiency among native and non-native speakers who are preservice teachers.

\section{Methodology}

This study was conducted by using quantitative method of survey study. It took a closer look at the integrative and instrumental motivations among Chinese language preservice teachers; and concluded with some implications on Chinese language preservice teachers.

\section{Research Objective}

Objectives of this study are as follows:

1. To identify integrative and instrumental motivations among the Chinese Language preservice teachers.

2. To identify the Chinese Language proficiency of preservice teachers.

3. To identify the different mean of Chinese proficiency between undergraduate with postgraduate teacher education programs.

4. To identify the different mean of integrative and instrumental motivation between undergraduate with postgraduate teacher education program.

\section{Sampling}

The population for this study were undergraduates and postgraduates comprising Malaysian preservice teachers from teacher training institutes. The random sampling method was used to collect data from every Chinese language unit in 8 teacher training campuses in Peninsular Malaysia. The questionnaire and Chinese proficiency test papers were sent to campuses and administered by lectures after lessons. 407 Chinese proficiency test papers and questionnaires were received. The breakdown of samples from teacher education programs is shown in Table 1

Table 1. Samples from Teacher Education Programs

\begin{tabular}{lccc}
\hline Group & Undergraduate & Postgraduate & Total \\
\hline Native speaks & 275 & -- & 275 \\
Non-native speaks & -- & 132 & 132 \\
Total & 275 & 132 & 407 \\
\hline
\end{tabular}

The survey on two teacher education groups: undergraduate preservice teachers who are native speakers (Chinese) and postgraduate diploma preservice teachers who are non-native speakers (Malays). The native speakers can communicate in other dialects of Chinese and 11 years of Chinese education background (primary and secondary school). The non-native speakers' group comprised Malay students pursuing the 4 years postgraduate course in Mandarin as a foreign language from a China university.

\section{Instrumentation}

The instrument comprised a survey questionnaire and proficiency test. The survey questionnaire was adapted and modified by Larisa Niktina, Don, and Loh (2016), consisting two subscales: (a) a 5-item 
INTERNATIONAL JOURNAL OF ACADEMIC RESEARCH IN BUSINESS AND SOCIAL SCIENCES

Vol. 9, No. 6, June, 2019, E-ISSN: 2222-6990 @ 2019 HRMARS

Integrative motivation scale (ORI), and (b) a 5-item Instrumental motivation scale (ORT). The scale for the survey questionnaire items was a 5-point Likert scale, ranging from 'Strongly Disagree' (1) to 'Strong Agree' (5), with values of the alternatives from 1 to 5 respectively.

The Chinese proficiency test was developed by the authors using Chinese language teacher education references. This test paper contained 40 objective questions that were divided into Chinese Culture (20 questions) and Chinese Grammar (20 questions). The result was converted to 5 grades, ranging from " $A$ " to " $D$ ".

All respondents answered the test paper in 1 hour and then filled the motivation questionnaires which lasted for 25 minutes.

\section{Results}

In the descriptive analysis, this study interpreted the mean scores using the following scale: Scale low=mean score 1 through 2; Scale low moderate=mean score 2 through 3; Scale moderate high=mean score 3 through 4, high=mean score 4 through 5 (Nunnally \& Bernstein, 1994). In this study, integrative and instrumental motivations were divided into two different teacher training programs, namely undergraduate and postgraduate programs.

Table 2. Integrative Motivation for Chinese Teacher Education Programs

\begin{tabular}{|c|c|c|c|c|c|c|c|c|}
\hline Program & & Under & radua & & & Postgr & adua & \\
\hline Item & Median & Mean & SD & Interpreter & Median & Mean & SD & Interpreter \\
\hline $\begin{array}{l}\text { ORI_1: I am } \\
\text { interested in Chinese } \\
\text { popular culture. }\end{array}$ & 5 & 4.46 & .61 & High & 4 & 4.13 & .74 & High \\
\hline $\begin{array}{l}\text { ORI_2: It will enable } \\
\text { me to better } \\
\text { understand Chinese } \\
\text { community's way of } \\
\text { life. }\end{array}$ & 4 & 4.10 & .81 & High & 4 & 3.64 & .92 & $\begin{array}{c}\text { Moderate } \\
\text { high }\end{array}$ \\
\hline $\begin{array}{l}\text { ORI_3: To learn } \\
\text { Chinese I have to get } \\
\text { to know its speakers } \\
\text { better. }\end{array}$ & 4 & 3.96 & .86 & $\begin{array}{l}\text { Moderate } \\
\text { high }\end{array}$ & 4 & 4.42 & .62 & High \\
\hline $\begin{array}{l}\text { ORI_4: It will enable } \\
\text { me to appreciate } \\
\text { Chinese art and } \\
\text { literature. }\end{array}$ & 4 & 4.34 & .95 & High & 4 & 3.84 & .77 & $\begin{array}{c}\text { Moderate } \\
\text { high }\end{array}$ \\
\hline $\begin{array}{l}\text { ORI_5: To understand } \\
\text { the Chinese people's } \\
\text { way of life. }\end{array}$ & 4 & 3.71 & 1.03 & $\begin{array}{l}\text { Moderate } \\
\text { high }\end{array}$ & 4 & 3.95 & .86 & $\begin{array}{c}\text { Moderate } \\
\text { high }\end{array}$ \\
\hline overall Mean & & 4.11 & .60 & High & & 4.00 & .49 & High \\
\hline
\end{tabular}


INTERNATIONAL JOURNAL OF ACADEMIC RESEARCH IN BUSINESS AND SOCIAL SCIENCES Vol. 9, No. 6, June, 2019, E-ISSN: 2222-6990 @ 2019 HRMARS

Table 2 shows that the overall mean score for integrative motivation was high amongst undergraduate Chinese preservice teachers $(M=4.11, S D=.60)$ and postgraduate diploma Chinese preservice teachers $(M=4.00, S D=.49)$ who responded to the questionnaire. The median score shows that the majority of preservice teachers scored 4 for all items, except for item ORI1, which received a median score of 5 from undergraduate Chinese preservice teachers.

When comparing the mean score, the finding revealed the difference in the mean score for both teacher education programs. In reference to the undergraduate Chinese preservice teachers, it was found that items ORI_1 (Median=5, M=4.46, SD=.61), ORI_2 (Median=4, M=4.10, SD=.81), and ORI_4 (Median=4, $M=4.34, S D=.95$ ) had a high mean score. Meanwhile, ORI_ 3 (Median=4, $M=3.96$, $\mathrm{SD}=.86$ ) and ORI_5 (Median=4, $\mathrm{M}=3.71, \mathrm{SD}=1.03$ ) had a moderate high mean score. The mean score for postgraduate diploma Chinese preservice teachers showed that the mean score for items ORI_1 (Median=4, $M=4.13, S D=.74$ ) and ORI_3 (Median=4, $M=4.42, S D=.62$ ) were high, but the mean score for items ORI_2 (Median=4, $M=3.64, S D=.92$ ), ORI_4 (Median=4, M=3.84, SD=.77) and ORI_5 (Median=4, M=3.95, SD=.86) were moderately high.

The results show that both teacher education programs agreed that study the Chinese Language related to Chinese modern culture. However, undergraduate Chinese preservice teachers were interested in understanding the Chinese community's lifestyle as well as Chinese art and literature. Meanwhile, the postgraduate diploma Chinese preservice teachers tended to know the native speakers better and the Chinese people's lifestyle based on integrative motivation.

Table 3. Instrumental Motivation for Chinese Teacher Education Programs

\begin{tabular}{|c|c|c|c|c|c|c|c|c|}
\hline Program & \multicolumn{4}{|c|}{ Undergraduate } & \multicolumn{4}{|c|}{ Postgraduate } \\
\hline Item & Median & Mean & SD & Interpreter & Median & Mean & SD & Interpreter \\
\hline $\begin{array}{l}\text { ORT_1: Chinese will } \\
\text { help me when I } \\
\text { travel abroad. }\end{array}$ & 4 & 4.29 & .79 & High & 4 & 3.58 & .94 & $\begin{array}{l}\text { Moderate } \\
\text { High }\end{array}$ \\
\hline $\begin{array}{l}\text { ORT_2: Chinese is } \\
\text { an important } \\
\text { language }\end{array}$ & 4 & 4.33 & .68 & High & 4 & 4.19 & .71 & High \\
\hline $\begin{array}{l}\text { ORT_3: Chinese can } \\
\text { be useful when I } \\
\text { further my studies }\end{array}$ & 5 & 4.70 & .52 & High & 5 & 4.62 & .70 & High \\
\hline $\begin{array}{l}\text { ORT_4: Chinese can } \\
\text { provide me with } \\
\text { some financial } \\
\text { benefits }\end{array}$ & 4 & 4.23 & .93 & High & 4 & 4.11 & .84 & High \\
\hline $\begin{array}{l}\text { ORT_5: Chinese will } \\
\text { be useful for my } \\
\text { future career. }\end{array}$ & 5 & 4.41 & .67 & High & 4 & 4.17 & .77 & High \\
\hline Overall Mean & & 4.39 & .48 & High & & 4.13 & .53 & High \\
\hline
\end{tabular}


INTERNATIONAL JOURNAL OF ACADEMIC RESEARCH IN BUSINESS AND SOCIAL SCIENCES Vol. 9, No. 6, June, 2019, E-ISSN: 2222-6990 @ 2019 HRMARS

Table 3 shows that the overall mean score for instrumental motivation was high amongst undergraduate Chinese preservice teachers $(M=4.39, S D=.48)$ and postgraduate diploma Chinese preservice teachers $(M=4.13, S D=.53)$, who responded to the questionnaires. The median score showed that the majority of preservice teachers indicated a median score of 4 for all items, except item ORT_3, which received a median score of 5 from both teacher education programs while ORT_5 received a median score of 5 from undergraduate Chinese preservice teachers.

Comparing the mean score revealed that the mean score for both teacher programs were almost similar. Referring to undergraduate Chinese preservice teachers, it was found that all items received a high mean score, such as items ORT_1 (Median=4, $M=4.29, S D=.79$ ), ORT_2 (Median=4, $\mathrm{M}=4.33, \mathrm{SD}=.68$ ), and ORT_3 (Median=5, $\mathrm{M}=4.70, \mathrm{SD}=.52$ ), ORT_4 (Median=5, $\mathrm{M}=4.23, \mathrm{SD}=.93$ ), and ORT_5 (Median=5, M=4.41, SD=.67). Meanwhile, the mean score for postgraduate diploma Chinese preservice teachers showed that item ORT_1 (Median=4, $M=3.58, S D=.94$ ) was at a moderate high mean score, but items ORT_2 (Median=4, $M=4.19, S D=.71$ ), ORT_3 (Median=5, $M=4.62, S D=.70$ ), ORT_4 (Median=4, $M=4.11, S D=.84$ ) and ORT_5 (Median=4, $M=4.17, S D=.77$ ) received a high mean score. The results show that undergraduate and postgraduate diploma Chinese preservice teachers were more concerned about their social status, future studies and career under the instrumental motivation.

In the Chinese proficiency test, this study interpreted the achievement level by using a mean score grade as follows: Extension= a score of 75 to 100; Distinction= a score of 60 to 74; Pass $=40$ to 59, Fail= score 0 to 39. In this study, the Chinese proficiency test was divided into two parts, which were the grammar and Chinese culture tests.

Table 4. Chinese Proficiency Test

\begin{tabular}{llccccc}
\hline Program & Test & Minimum & Maximum & SD & M & Level \\
\hline Undergraduate & $\begin{array}{l}\text { Grammar } \\
\text { Chinese }\end{array}$ & 35 & 95 & 10.74 & 63 & $\begin{array}{c}\text { Distinction } \\
\text { Distinction }\end{array}$ \\
& $\begin{array}{l}\text { Culture } \\
\text { Mean Overall }\end{array}$ & 35 & 100 & 13.54 & 70 & Distinction \\
\hline Postgraduate & Grammar & 20 & 85 & 13.08 & 51 & Pass \\
& $\begin{array}{l}\text { Chinese } \\
\text { Culture }\end{array}$ & 10 & 75 & 12.98 & 39 & Fail \\
& & 28 & 70 & 9.57 & 45 & Pass \\
\hline Overall Mean & & & & & & \\
\hline
\end{tabular}

Tables 4 shows the descriptive statistics for different proficiency tests. The results show that undergraduate Chinese preservice teachers scored high means with distinction scores for Grammar $(M=63, S D=10.74)$, Chinese Culture $(M=70, S D=13.54)$ and overall mean $(M=66, S D=10.16)$. Meanwhile, postgraduate diploma Chinese preservice teachers' mean score for the grammar test was a pass $(M=51, S D=13.08)$, a fail for Chinese Culture $(M=39, S D=12.98)$ and the overall mean was a pass $(M=45, S D=9.57)$. The result shows that there was a difference in Chinese test achievements between undergraduate and postgraduate diploma teacher education programs. 
INTERNATIONAL JOURNAL OF ACADEMIC RESEARCH IN BUSINESS AND SOCIAL SCIENCES Vol. 9, No. 6, June, 2019, E-ISSN: 2222-6990 @ 2019 HRMARS

Table 5. Analysis of Chinese Proficiency, Integrative and Instrumental Motivation for Teacher Education Programs

\begin{tabular}{llcccccc}
\hline Variable & Program & N & Mean & SD & $t$ & $d f$ & $p$ \\
\hline Chinese Culture & Undergraduate & 275 & 69.67 & 13.54 & 21.49 & 405 & .000 \\
Test & Postgraduate & 132 & 39.28 & 12.98 & & & \\
Chinese Grammar & Undergraduate & 275 & 62.75 & 10.74 & 9.71 & 405 & .000 \\
Test & Postgraduate & 132 & 50.87 & 13.08 & & & \\
Integrative & Undergraduate & 275 & 4.11 & .60 & 2.08 & 405 & .039 \\
Motivation & Postgraduate & 132 & 4.00 & .49 & & & \\
Instrumental & Undergraduate & 275 & 4.39 & .48 & 4.71 & 405 & .000 \\
Motivation & Postgraduate & 132 & 4.13 & .53 & & & \\
\hline$p<.05$ (2-tailed) & & & & & & &
\end{tabular}

The $t$ test (in Table 5) shows a significant difference between the Chinese Culture test score for undergraduate Chinese preservice teachers $(n=275, M=69.67, S D=13.54)$ and postgraduate diploma Chinese preservice teachers $(n=132, M=39.28, S D=12.98)$ that $t(405)=21.49, p<.01$. The Chinese grammar test showed a significant difference in test scores between undergraduate Chinese preservice teachers $(n=275, M=62.75, S D=10.74)$ and postgraduate diploma Chinese preservice teachers $(n=132, M=50.87, S D=13.08)$, that $t(405)=9.71, p<.01$. Based on the results, it can be concluded that the undergraduate Chinese preservice teachers' Chinese Language proficiency level was better than the postgraduate diploma Chinese teachers. Therefore, the postgraduate diploma teachers should put more afford in learning the Chinese language, especially Chinese culture.

The $t$-test result for integrative and instrumental motivations found that there was no significant difference in integrative motivation between undergraduate Chinese preservice teachers $(n=275, M=4.11, S D=.60)$ and postgraduate diploma Chinese preservice teachers $(n=132, M=4.00$, $S D=.49)$, that $t(405)=1.94, p>.05$. The instrumental motivation showed significant difference between undergraduate Chinese preservice teachers $(n=275, M=4.39, S D=.48)$ and postgraduate diploma Chinese preservice teachers $(n=132, M=4.13, S D=.53)$, that $t(405)=4.88, p<.01$. This reveals that undergraduate Chinese preservice teachers tend to embrace both integrative and instrumental motivations. Therefore, the postgraduate diploma teacher education program planner should pay more attention to integrative and instrumental motivations related to language learning environment and achievement.

\section{Discussion and Conclusion}

The findings show that there is a difference in Chinese proficiency between the undergraduate and postgraduate diploma Chinese preservice teachers. The undergraduate Chinese preservice teachers possessed a better mastery of the Chinese language and culture compared to the postgraduate diploma Chinese language preservice teachers. The difference in Chinese language proficiency could be related to the background of the respondents and their Chinese education experiences.

The findings were in accordance with the social education model (Gardner, 2001), which emphasized that the individual's belief and history were positively related to the learning motivation and orientation. Thus, if someone experienced the interest and pleasure in learning the Chinese 
language, it would enhance their confidence for learning it. Therefore, belief and history will change the Chinese preservice teachers' behaviour, motivation and attitude in their Chinese Language performance.

According to Gardner (2001), the learning environment directly influences the individual's integrative and instrumental motivations. Gardner (2006) explained that social and education contexts can change the individual's motivation to resist cultural contact, language retention, classroom behaviour as well as language achievement and use. The findings indicate that the two preservice teacher education programs scored a high mean score in integrative and instrumental motivation. In this case, the Chinese preservice teachers emphasized the importance of cultural contact and language retention. Thus, if they wanted to master the Chinese language, they should learn Chinese culture because language is the symbol of a culture. Therefore, cultural knowledge directly influences language performance (Gardner, 1985; 2001).

The result of mean compares of integrative and instrumental motivation revealed that the undergraduate Chinese preservice teachers' mean score was higher than that of postgraduate diploma Chinese preservice teachers. This was due to the undergraduate preservice teachers being ethnic Chinese who were familiar with Chinese culture and living. The finding was supported by Lee and Cao (2015), who stated that different ethnic groups, age, and gender in Malaysian Chinese learners had different integrative and instrumental motivations. Heida and Shabudin (2014) also indicated that culture and culture engagement influenced the integrative motivation in language learning.

One of the different points of the study revealed that non-native speakers who are Chinese preservice teachers demonstrated openness to cultural identification. They were interested in modern Chinese culture, getting better acquainted with native speakers, and understanding the Chinese people's way of life under the integrative motivation component. From this perspective, the integrative motive intended to encourage non-native speakers of Chinese preservice teachers to engage in Chinese social work to promote language acquisition and mastery of the Chinese language and culture (Gardner, 2006). However, the findings differed with that of Zhen (2015), who emphasized that Sinosphere students were comfortable in engaging Chinese cultural activity compared to non-Sinosphere students who were more instrumental in learning Mandarin.

This study provides meaningful information regarding Chinese Language studies on Chinese teacher education programs. Integrative and instrumental motivation were important predictors of Chinese language proficiency and academic achievement. The study suggested that Chinese communities and schools should support and provide an opportunity for Chinese preservice teachers, especially non-Chinese speakers, to participate in social work and self-exploration of Chinese culture. Engaging in social work will enhance the level of Chinese mastery and cultural knowledge of nonnative speakers and portray the self-identity of Chinese native speakers. This study hopes to will shed some light on the importance of maintaining heritage language, justifying such educational reforms, and overcoming the existing problems.

\section{Corresponding Author}

Tan Chor Ter, Department of Language and Literacy Education Faculty of Education, University of Malaya, Malaysia. Email: tchorter@gmail.com 
INTERNATIONAL JOURNAL OF ACADEMIC RESEARCH IN BUSINESS AND SOCIAL SCIENCES

Vol. 9, No. 6, June, 2019, E-ISSN: 2222-6990 @ 2019 HRMARS

\section{References}

Ghazali, A. Z., \& Mahmud, N. A. N. (2008). History of Malaysia Teachers. Putrajaya: Ministry of Education Malaysia.

Foo, S. F. (2005). Teachers Ethical. Serdang: University Putra Malaysia Press.

Mora, J. C. \& Darcy, I. (2017). The relationship between cognitive Control and pronunciation in a second Language. In Mora, J.C. \& Darcy, I. (Eds), Second Language Pronunciation Assessment: Interdisciplinary Perspectives (pp. 95-120). Bristol: Multilingual Matters.

Neo, K. S. (2011). Chinese language and Chinese culture. Selangor: UiTM press.

Ng, P. H. Wong, S. B. Tan, K. C. Guek, Y. H. \& Lim, W. H. (2017). The case study on the level of oral proficiency of the teacher of the post graduate diploma program who graduated from the Chinese Language as a second language from Beijing. Jurnal Pendidikan Bahasa, 79-86.

Koh, S.T. (2008). Attitudes towards the Mandarin usage among Chinese in Malaysia: A case study. Dissertation (M.M.L.S). University Malaya, 2008.

Adler, S. (2008). "The education of social studies teachers". In Levstik, L S.\& Tyson, C A. (Eds), Handbook of research on social studies education (pp.329-351). UK: Routledge.

Cui, X. L. (2010). On the "three concerns" of teaching Chinese as a second language. Chinese teaching in the world, 1, 73-81.

Guo, F. L. (2012). Considerations on the Training of overseas Chinese teaching staff. Language teaching and Linguistic Studies, 2, 33-38.

Gardner, R. C. \& Lambert, W. E. (1972). Attitude and motivation in second language learning. Rowley, MA: Newbury House.

Gardner, R. C. (1985). Social psychology and second language learning. London, UK: Edward Arnold.

Gardner, R. C. (2001). Language learning motivation: The student, the teacher, and the researcher. Foreign Language Education 6: 1-18.

Gardner, R. C (2006). Motivation and Attitudes in Second Language Learning. Encyclopedia Of Language \& Linguistics: 348-355.

Gardner, R. C., Masgoret, A. M., Tennant, J., \& Mihic, L. (2004). Integrative motivation: Changes during a year-long intermediate-level language course. Language Learning, 54(1), 1-34.

MOE. (2013). Malaysian Education Blueprint 2012-2025. Putrajaya: Ministry of Education Malaysia.

Lai, M. L. (2005). Language attitudes of the first postcolonial generation in Hong Kong secondary schools. Language in Society, 34(4), 363-388.

Lai, M. L. (2011). Cultural identity and language attitudes into the second decade of postcolonial Hong Kong. Jurnal of Multilanguage and Multicultural Development,32 (3), 249-264.

Lai, M. L. (2013). Impacts of medium of instruction on language attitudes: A case of Hong Kong. AsiaPacific Edu Res, 22, 61-68.

Lam, Y.C. Yau, Y.S. Yeo, C.E. Chew, C.K. Lee, S.P. \& Lee, V.L. (2006). The preservice teachers' efficiency in teaching and learning Chinese reading. Jurnal Penyelidikan IPBL 7, 48-54.

Niktina, L., Zuraidah, Mhd.D. \& Lau, S.C. (2016). Construction and validation of a questionnaire on language learning Motivation. Зборник Института за педагошка истраживања Година, 48(2), 284-300.

Heida, H., \& Shabudin, M. (2014). Attitudes towards Japanese language among Malaysian Students. GEMA online journal of language studies, 14(1), 135-150. 
INTERNATIONAL JOURNAL OF ACADEMIC RESEARCH IN BUSINESS AND SOCIAL SCIENCES

Vol. 9, No. 6, June, 2019, E-ISSN: 2222-6990 @ 2019 HRMARS

Zheng, R. (2015), A stdudy of silf determination motivation comparison between sinosphere and the non sinosphere students in Chinese learning---Take Anhui University for example. Dissertation An Hui University. 